\title{
能功的功吸振器の研究*
}

$$
\begin{aligned}
& \text { 背 戸 一 } \text { 登*1, }^{* 1} \text { 猿 渡 克 己*2 } \\
& \text { 藤 田 勝 久 }
\end{aligned}
$$

\section{A Study on Active Dynamic Absorbers}

\author{
Kazuto SETO, Katumi SAWATARI, Katushisa FUJITA and Yoshirou FURUISHI
}

\begin{abstract}
Although it is known that active dynamic absorbers are useful for controlling the vibration of structures, the design method for popular usage has not yet been established. This paper proposes the design method of the active dynamic absorber by the use of the LQ optimum control theory. First. nondimensional representations of the state space formulation of the structure and active dynamic absorber system, the state feedback gain matrix, and the weight matrix are constructed to obtain a generality. Secondly, the relationship between the vibration control effect and parameters of the weight matrix are clarified for designing. The design data are prepared as the nondimensional root locus, the frequency response, and the impulse response charts. The effectiveness of the active dynamic absorber designed through this method is demonstrated experimentally.
\end{abstract}

Key Words: Vibration, Vibration Control, Control Device, Damper, Active Dynamic Absorber

\section{1. 緒}

最近，機械装置に限らず，乗り物，土木建築構造物， 宇宙構造物など, 各方面で振動に起因する障害を防止 して、機能，性能の維持向上を図るために制振装置の 研究が盛んになってきた (1). 制振装置は受動形と能動 形に大別されるが、動吸振器は受動的制振装置を代表 する制振装置である。これは，補助質量を反力として 制振力を得ているために取付場所の制約を受けること が少なく、また，質量とばね，およびダンパの 3 要素 に巧妙な動力学的バランスを持たせることによって優 れた制振効果を作り出しているので，広く使用されて いる。最近では，動吸振器による多自由度系の制振理 論も明らかにされており(2)，さらに応用面が拡大され る動向にある(3).

ところが，動吸振器はセンサという目を持たないた めに，制振対象やこ机自身の特性に変化があった場合 に応ずることができない，特に，質量比が小さい場合

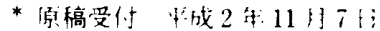

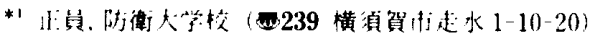

*2 萔衙大学校。

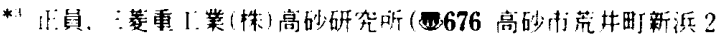
$-1-1)$.

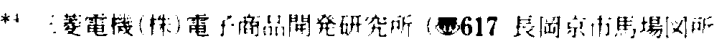

その問題が顕著に現れる。そこで, 二重動吸振器や磁 気減衰動吸振器の提案があり，その問題がある程度緩 和できることが示されたのである(4)が, 特性変化が大 きい場合には，根本的解決に至っていない。

一方, 最近この問題を補完できる能動的動吸振器が 注目されるようになってきた。アクティブマスダンパ とも呼ばれており，高首建築物の振動制御に盛んに応 用されようとしている(5) (8).これは，制振対象や吸振 器質量の変位や速度をセンサで測定してこれらの物理 量を状態フィードバックするので，前記の特性変化に 対してロバスト性がある。この制御系の設計には，主 にLQあるいは LQG 制御理論が用いられている。こ の吸振器の開発研究が活性化した背景には，LQ理論 を実現するコンピュータの利用技術の発達が挙げられ る。特に、状態フィードバック制御則を決定するリカ ッチ方程式がパーソナルコンピュータで容易に解ける ようになったことの意義は大きい。

その反面，重み係数や重み行列を適当に与えるだけ でこのフィードバック制御則はブラックボックス的に 決定さ扎るので，今まで行われてきた一連の研究はケ ーススタディに留まって抢り一般性に久ける。したが つて，LQ理論に上る能動的動吸振器の設計法や制振 性能が十分に解明されているとは言いがたい。 
そこで, 本研究では, 電磁アクチュエータを用いた 能動的動吸振器を構成し，これを $\mathrm{LQ}$ 制御理論を用い て制御した時の制振性能を明らかにしようとするもの である。まず，一般性のある結果が得られるように制 御系を無次元化表示した後,制御系設計の指針を得る ために制振効果と重み係数や重み行列の関わりについ て解明する。ついで, 制振効果とアクチュエータの動 特性の関係を明らかにする。ささらに，吸振器構造と省 エネルギー化設計の関わりの知見を得ようとしてい る。最後に，得られた結果について実験によって検証 する。

\section{本論文で用いる主な記号}

$$
\begin{aligned}
& M \text { : 制振対象質量 } \mathrm{kg} \\
& K: \text { 制振対象のばね定数 } \mathrm{N} / \mathrm{m} \\
& m: \text { アクティブ質量 } \mathrm{kg} \\
& k \text { :支持ば权定数 } \mathrm{N} / \mathrm{m} \\
& L: \text { 駆動コイルのインダクタンス } \mathrm{H} \\
& R_{c} \text { : 慪動コイルの抵抗 } \Omega \\
& T \text { : 時定数 }(L / R) \mathrm{s}^{-1} \\
& X: \text { 制振対象の変位 } \mathrm{m} \\
& x: \text { アクティブ質量の変位 } \mathrm{m} \\
& x_{d}: \text { 相対変位 }(x-X) \quad \mathrm{m} \\
& f_{c}: \text { 制振力 } \mathrm{N} \\
& f_{d} \text { : 外力 } \mathrm{N} \\
& e_{c}: \text { 制御電压 } \mathrm{V} \\
& I: \text { 駆動電流 } \mathrm{A} \\
& K_{c} \text { :アクチュエータの力倸数 N/A } \\
& K_{s} \text { : 変位センサの変換係数 } \mathrm{V} / \mathrm{m} \\
& K_{v}: \text { 外力の変換係数 } \mathrm{N} / \mathrm{V} \\
& \mu: \text { 質量比 }=m / M \\
& \Omega_{n}: \text { 制振対象の固有振動数 }=\sqrt{K / M} \\
& \omega_{n} \text { : 能動的動吸振器の固有振動数 } \sqrt{k / m} \\
& \gamma: \text { 固有振動比 }=\omega_{n} / \Omega_{n} \\
& \tau: \text { 時定数比 }=1 / T / \Omega_{n} \\
& K: \text { 状態つィードバックゲインベクトル } \\
& \text { - : 無次元量 }
\end{aligned}
$$

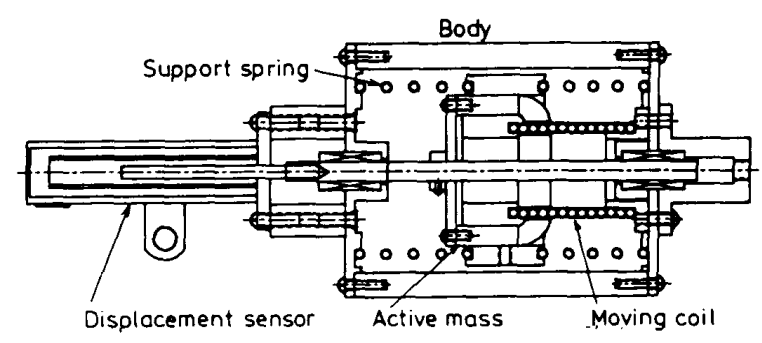

図 1 本能動的動吸振器の構造

\section{2. 本能趵的功吸振器の棰造}

今までに提案されている能動的動吸振器は,アク チュエータに注入する動力源の相違によって，油圧力と 電磁力方式に大別される. また, 補助質量の駆動方式 によって、リニヤ駆動方式とモータ駆動方式がある。 前者は補助質量を直動する方式であり，後者はサーボ モータによってボールねじを回転することによって間 接的に補助質量を直動させる方式である。補助質量の 支持方法によっても，吊り下げ支持，ばね支持，案内 面支持など方式が採られている。この補助質量はアク ティブに制卸されるので,アクティフ質量と呼ばれる ことが多い。

著者らは，すでに 2 種類の電磁カリニヤ駆動による ばね支持方式の能動的動吸振器(9)(10)を提案したが，本 研究では一般性を考虑して，図1に示すような標準的 な能動的動吸振器の駆動部を構成した。これ、リン グ状磁気回路を有するアクティブ質量，これを両側か ら支える補助ばね, 駆動コイル，制振対象への取付部 を有する本体，および，本体とアクティフ質量間の相 対変位を検出する変位センサより成っている。アク ティブ質量はリニヤ案内面で支持されているので，この 能動的動吸振器は案内面支持に上る電磁力式りニヤア クチュエータ方式である.

図 2 は，1 自由度系の制振対象に取付けられた能動 的動吸振器の構造を示す。本動吸振器は, 図 1 に示し な駆動部とコントローラ部より成っている.コントロ 一ラでは，2 個の変位センサによって検出された制振 対象の絶対変位 $X$ と前記相対変位 $x_{d}$ から, 各速度信 号 $\dot{X}, \dot{x}_{d}$ を作り出し、また制御電流 $I$ も検出して, こ れらの五つの信号にフィードバックゲインを乗算して 状態フィードバックの制御量 $u$ を作り出している。こ の構造の特徵は、センサと駆動部、それにコントロー

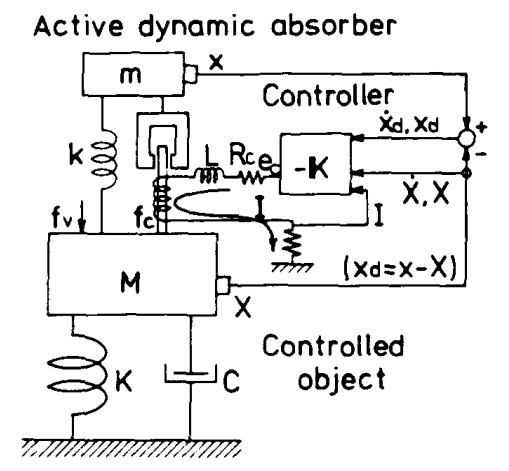

図 21 自由度系の制御対象に取付けられた能動的動吸振 器 
ラが一体になってお゙り，綎置き，横目き自在であって，取付方向に制約がないのて応用面が広いことである。

\section{3. 状態方程式による眍述と制御系設䑒}

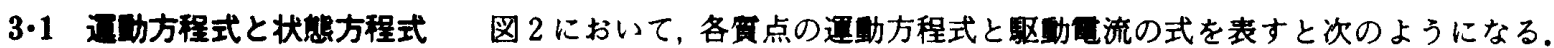

$$
\begin{aligned}
& \ddot{X}=\frac{1}{M}\left\{-K X-C \dot{X}+k(x-X)+f_{v}+f_{c}\right\} \\
& \left.\ddot{x}=\frac{1}{m}\left\{-k(x-X)-f_{c}\right)\right\} \\
& \dot{I}=\frac{1}{L}\left(-R_{c} I+e_{c}-e_{b}\right) \\
& f_{c}=K_{\mathrm{c}} I \\
& e_{b}=-K_{b}(\dot{x}-\dot{X})
\end{aligned}
$$

ここに, $K_{c}$ は力係数, $K_{b}$ は逆起電力係数であり， $e_{c}, e_{b}$ は制御电压と逆起电力を示す。ここで, 相対変位を次の ように定義する。

$$
x_{d}=x-X
$$

この相対変位を用いて, 状䈍べクトルを以下のように定義する.

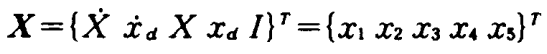

この状稳べクトルを用いて，式 $(1) 〜(5)$ の烕係を状態方程式で表すと次のようになる.

$$
\dot{\boldsymbol{X}}=\boldsymbol{A} \boldsymbol{X}+\boldsymbol{b} u+\boldsymbol{d} v
$$
ただし

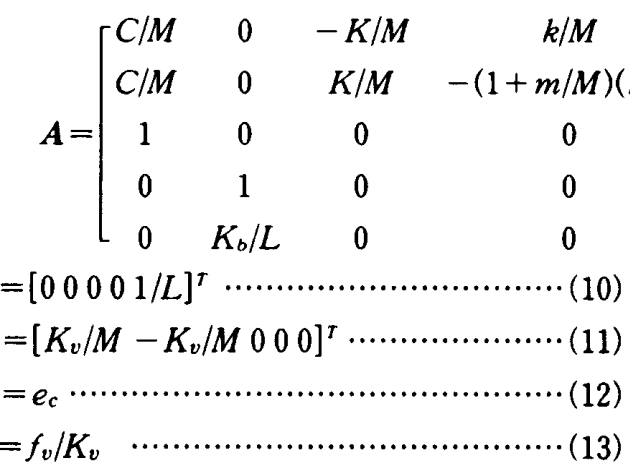

と定義する。ここに，T=L/Rcは時定数である.

また，注目されるのは制振対象の変位であるので出 力方程式は次のようになる。

$$
y=c \boldsymbol{X}
$$
ここに,

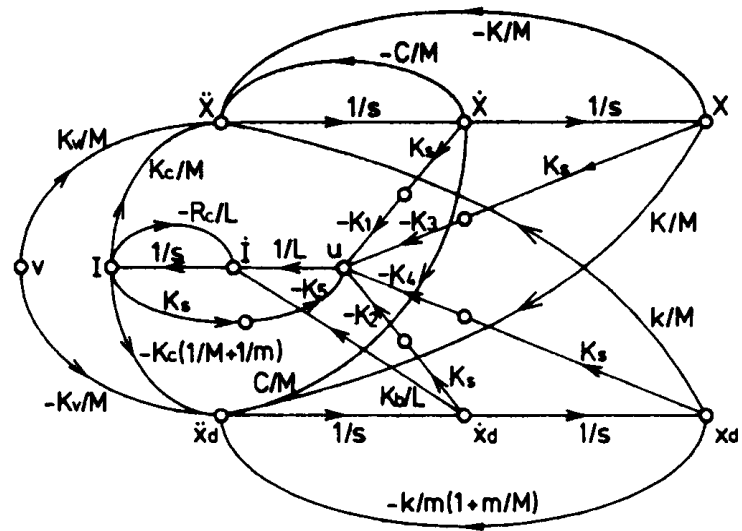

図3図2に示した振動制御系の佰号伝遣線図表示

$$
\left.\begin{array}{c}
K_{c} / M \\
-(1 / M+1 / m) K_{c} \\
0 \\
0 \\
-1 / T \\
c=\left[\begin{array}{lll}
0 & 0 & 1
\end{array}\right]
\end{array}\right]
$$

そこで,この能動的動吸振器においては，次のよう な状態フィードパックを施すようにする。

$$
\boldsymbol{u}=-\boldsymbol{K} \boldsymbol{X}
$$

ここで, 状態フィードバックゲィンベクトル $\boldsymbol{K}$ を次 のように定義する。

$$
\boldsymbol{K}=K_{s}\left\{k_{1} k_{2} k_{3} k_{4} k_{5}\right\}
$$

ここに，Ks は変位と電圧の変換係数である．式 $(7)$ 〜 (15)の咸係を信号伝達線図で表すと図 3 のようにな る.ただし， $s$ は微分演算子である。

よく知られているように，LQ制御理論を用いれば， 渐近安定が保証された制御系を構成するために，この ベクトル $\boldsymbol{K}$ の值をブラックボックスの状態で決定す ることができる。

3.2 無次元化状態方程式衰示 しかし，この状 態方程式のままで制御系を設計したのでは，能動的動 吸振器の一般的性貫をつかみ、一般性のある制御系設 計の資料を得ることができない。そこで，この問題に 对処するために，以下の手順で状態方程式の無次元化 を図る。まず，次のような無次元量を導入する。

$$
\begin{aligned}
& \mu=m / M \\
& \gamma=\omega_{n} / \Omega_{n}
\end{aligned}
$$




$$
\begin{aligned}
& \zeta=C /(2 \sqrt{K / M}) \\
& \tau=(1 / T) / \Omega_{n} \\
& \delta=K_{c} K_{b} \tau /\left(R_{c} M \Omega_{n}\right)
\end{aligned}
$$

ただし， $\omega_{n}=\sqrt{k / m}, \Omega_{n}=\sqrt{K / M}$ は各々動吸振器と制 振対象の固有振動数である。次に，下記のようなスケ 一ル変換係数を尊入する。

$$
\begin{aligned}
& s=\Omega_{n} p, \ddot{X}=\Omega_{n}{ }^{2} \overline{\dot{X}}, \dot{X}=\Omega_{n} \overline{\dot{X}}, X=\bar{X} \\
& t=\Omega_{n} t, \ddot{x}_{d}=\Omega_{n}{ }^{2} \overline{\dot{x}}_{d}, \dot{x}_{d}=\Omega_{n} \overline{\dot{x}}_{d}, x_{d}=\bar{x}_{d} \\
& u=\frac{R_{c} M}{K_{c}} \Omega_{n}{ }^{2} \bar{u}, \dot{I}=\frac{M}{K_{c}} \Omega_{n}{ }^{3} I \\
& I=\frac{M}{K_{c}} \Omega_{n}{ }^{2} \bar{I}, v=\frac{M}{K} \Omega_{n}{ }^{2} \bar{v}, \\
& k_{i}=\frac{R_{c} M}{K_{c} K_{s}} \Omega_{n} \bar{k}_{i}(i=1,2) \\
& k_{i}=\frac{R_{c} M}{K_{c} K_{s}} \Omega_{n}{ }^{2} \bar{k}_{i}(i=3,4) \\
& k_{5}=\frac{R_{c}}{K_{s}} \bar{k}_{5}
\end{aligned}
$$

これらの係数を用いれば, 次のような無次元化状態 方程式が得られる。

$$
\overline{\boldsymbol{X}}=\overline{\boldsymbol{A}} \overline{\boldsymbol{X}}+\overline{\boldsymbol{b}} \bar{u}+\overline{\boldsymbol{d}} \bar{v}
$$
ここに

$$
\overrightarrow{\boldsymbol{A}}=\left[\begin{array}{ccccc}
-2 \zeta & 0 & -1 & \mu \gamma^{2} & 1 \\
2 \zeta & 0 & 1 & -(1+\mu) \gamma^{2} & -(1+1 / \mu) \\
1 & 0 & 0 & 0 & 0 \\
0 & 1 & 0 & 0 & 0 \\
0 & \delta & 0 & 0 & -\tau
\end{array}\right]
$$

$$
\bar{b}=\left[\begin{array}{lllll}
0 & 0 & 0 & 0 & \tau
\end{array}\right]^{r}
$$

$\bar{d}=\left[\begin{array}{lllll}1 & -1 & 0 & 0 & 0\end{array}\right]^{T}$

また，制御量と状態フィードバック・ゲインベクトル も次のようになる.

$$
\begin{aligned}
& \overline{\boldsymbol{u}}=-\overline{\boldsymbol{K}} \overline{\boldsymbol{X}} \\
& \overline{\boldsymbol{K}}=\left\{\begin{array}{lllll}
\bar{k}_{1} & \bar{k}_{2} & \bar{k}_{3} & \bar{k}_{4} & \bar{k}_{5}
\end{array}\right\}
\end{aligned}
$$

なお，時定数 $T$ が無視できる場合には次数が一つ 下がって, 各行列とベクトルは次のように低次元化さ れる。

$$
\begin{aligned}
& \overline{\boldsymbol{X}}=\left\{\begin{array}{llll}
\bar{x}_{1} & \bar{x}_{2} & \bar{x}_{3} & \bar{x}_{4}
\end{array}\right\}^{T} \\
& \overline{\boldsymbol{A}}=\left[\begin{array}{cccc}
-2 \zeta & 0 & -1 \\
2 \zeta & 0 & 1 & \\
1 & 0 & 0 \\
0 & 1 & 0
\end{array}\right. \\
& \overline{\boldsymbol{b}}=\left[\begin{array}{llll}
1 & -(1+1 / \mu) & 0 & 0
\end{array}\right]^{T} \\
& \overline{\boldsymbol{d}}=\left[\begin{array}{lllll}
1 & -1 & 0 & 0
\end{array}\right]^{r} \ldots \ldots \ldots \ldots \\
& \overline{\boldsymbol{K}}=\left\{\begin{array}{llll}
\bar{k}_{1} & \bar{k}_{2} & \bar{k}_{3} & \bar{k}_{4}
\end{array}\right\}
\end{aligned}
$$$$
\bar{A}=\left[\begin{array}{cccc}
-2 \zeta & 0 & -1 & \mu \gamma^{2} \\
2 \zeta & 0 & 1 & -(1+\mu) \gamma^{2} \\
1 & 0 & 0 & 0 \\
0 & 1 & 0 & 0
\end{array}\right]
$$

$3 \cdot 3$ 制御系設計 制御系設計には LQ 制御理論 を用いる。この場合, 設計パラメータは次の評価関数
$J$ に与える重み行列 $\boldsymbol{Q}$ と重み係数 $R$ である.

$$
J=\int_{0}^{\infty}\left(\boldsymbol{X}^{T} \boldsymbol{Q X}+u^{2} R\right) d t
$$

LQ 制御理論に基づけば，この評価閔数を最小にする 制御量 $u$ は次のように定式化されている.

$$
u=-R^{-1} b^{T} P X=-K X
$$

ここに, $\boldsymbol{P}$ は次のリカッチ方程式の解である.

$$
\boldsymbol{P A}+\boldsymbol{A}^{T} \boldsymbol{P}-\boldsymbol{P b} R^{-1} \boldsymbol{b}^{T} \boldsymbol{P}+\boldsymbol{Q}=\mathbf{0}
$$

このリカッチ方程式を解くパッケージプログラムは用 意されているので，Kの值はブラックボックス的に 求まるのである。そして，この状態フィードバックを 施せば，例え不安定な制御系であっても，安定化が保 証されることが知られている。

ところが、設計パラメータ $Q, R$ の值と得られる制 御系の特性の関係が不明であるために，QやRの值 を試行錯誤的に与えて所用の制御系を設計しているの が現状である、そこで、この問題を解明し，解析結果に 一般性を持たせるために $\boldsymbol{Q}$ を次のように目く。

$$
\overline{\boldsymbol{Q}}=\left[\begin{array}{lllll}
q_{1} & 0 & 0 & 0 & 0 \\
0 & q_{2} & 0 & 0 & 0 \\
0 & 0 & q_{3} & 0 & 0 \\
0 & 0 & 0 & q_{4} & 0 \\
0 & 0 & 0 & 0 & q_{5}
\end{array}\right]
$$

ここに, $\overline{\boldsymbol{Q}} は \boldsymbol{Q}$ の無次元化した重み行列である.無次

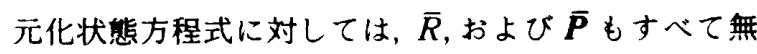
次元值を用いなければならない.

また,アクチュエータの時定数 $T$ が次の関係にあ ると仮定して，

$$
1 / T \gg \Omega_{n}
$$

$T$ の影響が無視できる場合は， $\boldsymbol{Q}$ を次の様に定める.

$$
\overline{\boldsymbol{Q}}=\left[\begin{array}{cccc}
q_{1} & 0 & 0 & 0 \\
0 & q_{2} & 0 & 0 \\
0 & 0 & q_{3} & 0 \\
0 & 0 & 0 & q_{4}
\end{array}\right]
$$

ここに,

$q_{1}$ : 制振対象の速度に掛かる無次元重み係数

$q_{2}:$ 相対速度に掛かる無次元重み係数

$q_{3}:$ 制振対象の変位に掛かる無次元重み係数

$q_{4}:$ 相対速度の変位に掛かる無次元重み係数

$q_{5}$ : 駆動コイルの電流に掛かる重み係数

$3 \cdot 4$ 相似則 LQ制御理論における無次元系と 次元系の間に成立する相似則は，著者らによって明ら かにされている(11)。それによると，状隹フィードバッ ク・ゲインベクトル $\boldsymbol{K}$ は次のような関係にある。

$$
\boldsymbol{K}=\frac{R_{c} M}{K_{c} K_{s}} \Omega_{n}{ }^{2}\left[\bar{k}_{1} / \Omega_{n} \bar{k}_{2} / \Omega_{n} \bar{k}_{3} \bar{k}_{4}\right]
$$


したがって, 無次元系のリカッチ方程式を解いて $\bar{k}_{1}$ 〜 $\bar{k}_{4}$ が定まれば, 制御系が設計できる。また, 重み行 列と重み係数の関係も次のような関係にある.

$$
\begin{aligned}
& \boldsymbol{Q}=\left[\begin{array}{ccc}
q_{1} / \Omega_{n}{ }^{2} & & 0 \\
q_{2} / \Omega_{n}{ }^{2} & & \\
& q_{3} & \\
0 & & q_{4}
\end{array}\right] \\
& R=\left[\frac{K_{c} K_{s}}{R_{c} M \Omega_{n}{ }^{2}}\right]^{2} \bar{R} \ldots \ldots
\end{aligned}
$$

以上の関係を用いれば，無次元系で得られた解析結果 は次元系にもそのまま適用できる。

\section{4. 制振効果の解析}

本研究では，まず式(32)の関係にあるとして $T$ の 影制を無視して, 制御系の特性と $q_{1}, q_{2}, q_{3}, q_{4}$ ，および $R$ の関係を明らかにする，ついで， $T$ の影響が無視で きない場合について考察する. 制振対象の減衰は無視 できることと, 質量比は制振性能には直接関与しない ことを考慮して，解析には次の值が用いられた。

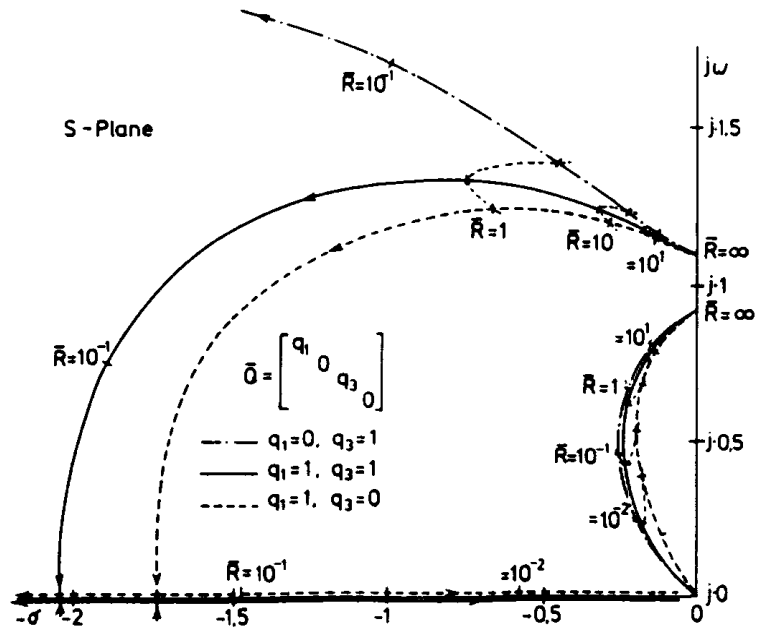

図 4 制振効果に及ほす重み係数 $q_{1}, q_{3}$, の 影響を示す根軌跡図

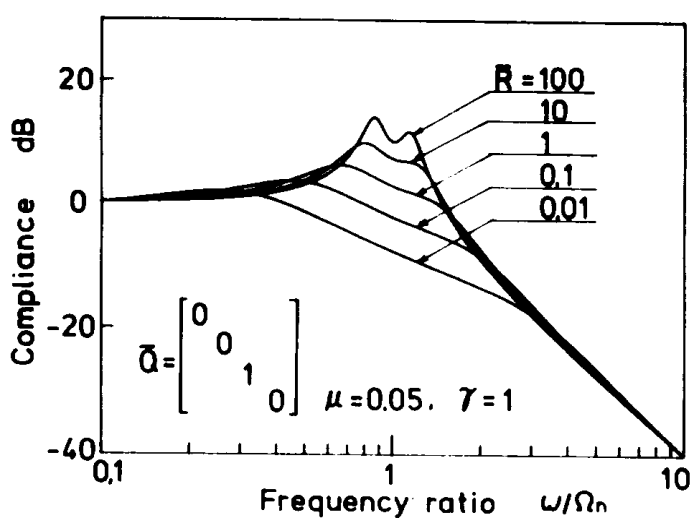

図 5 制振対象の変位に重みをかけた時の 周波数応答の特幑

$$
\zeta=0, \mu=0.05, \delta=0, \gamma=1
$$

最後に, $\gamma$ の影䇾についても明らかにする.

$4 \cdot 1$ 制振効果に及ほす $q_{1}, q_{3}$ の影誨 図 4 の一 点鎖線は制振対象の変位に重みを掛けたとき $\left(q_{3}=1\right.$, $\left.q_{1}=q_{2}=q_{4}=0\right)$ の根軌跡であり, 点線は速度に重みを 掛けたとき $\left(q_{1}=1, q_{2}=q_{3}=q_{4}=0\right)$ の根軌跡である。 た，実線は速度と変位の両方に重みを掛けた場合 $\left(q_{1}\right.$ $\left.=q_{3}=1, q_{2}=q_{4}=0\right)$ である. いずれも無次元重み係数 $R$ をパラメータとして変化させている．このことから 次のことがわかる.

（1） $q_{3}$ の役割は，虚軸上に近い二つの根の内，原 点に近い根を虚軸から離しながら原点に引き込み，他

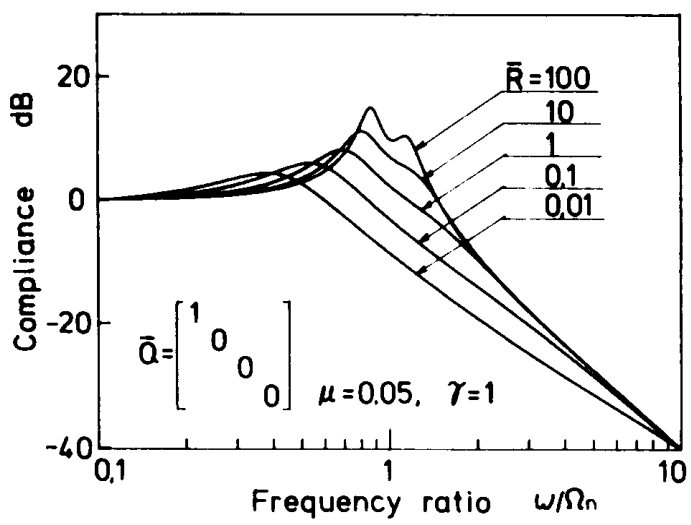

図 6 制振对象の速度に重みをかけた時の 周波数応答の特徵

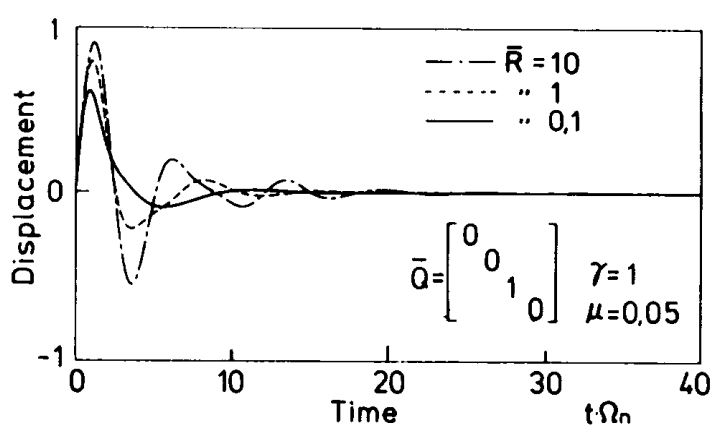

(a)

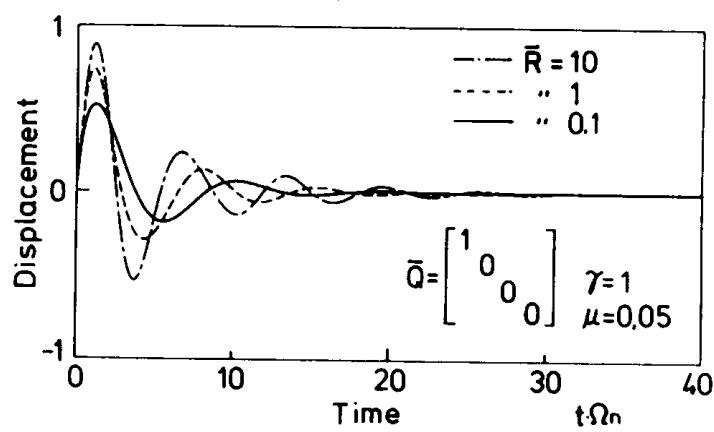

(b)

図 7 制振対象の変位と速度に重みを掛けた時の相違を 示寸無次元化インパルス応答 
の根を $s$ 平面の左遠方へ原点から離す働きをする。

（2） $q_{1}$ の役割は，虚軸に近い二つの根を虚軸から 離しながら原点に引き込む働きをする，そのため，原 点に近い根軌跡が虚軸から離れる度合が少ない。

（3） $q_{1}$ と $q_{3}$ を併用すると，原点に近い根軌跡は $q_{3}$ 単独の根軌跡に近づき，原点から遠い根軌跡は $q_{1}$ のそれに近づく。つまり，q $q_{3}$ は原点に近い根軌跡に大 きく影響して， $q_{1}$ は原点から遠い根軌跡に影響が大で ある.したがって， $q_{1}$ と $q_{3}$ の值の比を変えることによ つて， $q_{1}$ 単独と $q_{3}$ 単独の根軌跡で囲まれた空間内で 任意の根軌跡を得ることができる。

図 5 は，制振対象の変位にのみ重みをかけて，重み 係数 $\bar{R}$ を変えたときの制振対象の周波数応答である.

また，図 6 は，制振対象の速度にのみ重みをかけた 場合を示す。どちらも重み係数の隇少とともに共振ピ 一クは抑制され, 制振効果が向上しているが, 図 5 の ほうがより共振ピークの低下が顕著である。また,こ の場合 2 個のピークが両側に分かれる傾向にあるが， 図6では一つにまとまる傾向にある。

図 7 (a)は, 図 5 に対応するインパルス応答, 同図 (b) は図 6 に相当するインパルス応答である。この場 合も両者ともに $\bar{R} の$ 隇少に連れて制振効果が向上し

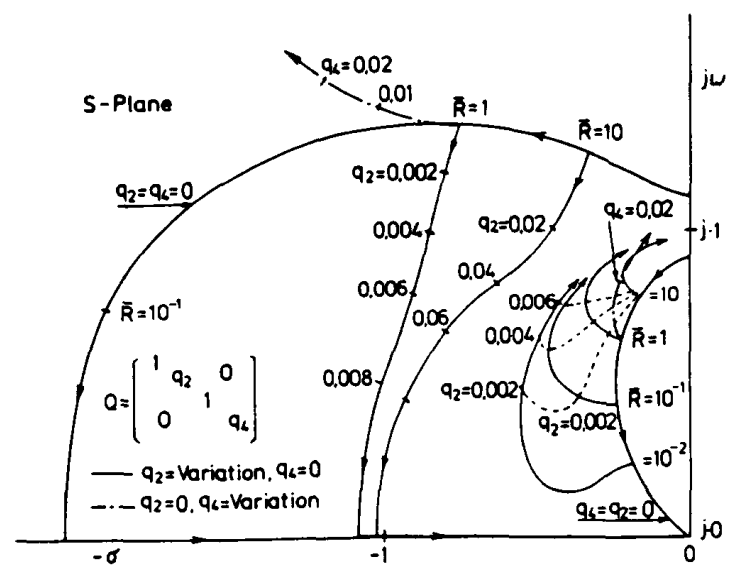

図 8 制振効果に及ほす重み係数 $q_{2}, q_{4}$ の 影管を示す根軌跡

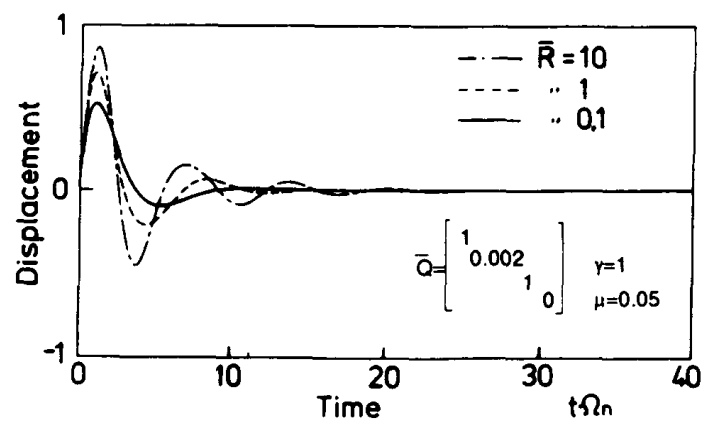

図 9 重み係数を $q_{1}=q_{3}=1, q_{4}=0, q_{4}=0, q_{2}=0.002$ に定め てRを変化させたときのインパルス応答の変化
ているが, 前者のほうが収束が速い。これらの応答と 根軌跡図の対応を理解しておくと制御系設計において 便利である。

$4 \cdot 2$ 制振効果に及ほす $q_{2}, q_{4}$ の影掣 次に, $q_{2}$ と $q_{4}$ の役割について調べる. 図 8 は, $\bar{R}$ の值を一定に 保ち， $q_{1}=q_{3}=1$ のもとで， $q_{4}$ を変えたときの根軌跡 を一点鎖線で，また $q_{2}$ を変えたときの根軌跡を実線 で示す.この図から次のことがわかる。

（1） $q_{2}$ の值を増加するに伴って，原点に近い根軌 跡はまず負の実軸側へ引き込まれて, 次に原点から離 れるように虚軸に接近する。逆に，原点から遠い根軌 跡は負の実軸側へ引き込まれる。したがって，q2に適 值を与えれば共振ピークは大いに低下して, 制振効果 の向上に寄与する. 図 9 は $q_{2}=0.002$ の值に定めて $\bar{R}$ を変えたときのインパルス応答である. 図 7 と比較し て制振効果が明らかに向上していることがわかる。

（2） $q_{4}$ の值を増加しても, 原点に近い根軌跡は虚 軸から離されるが，その効果は $q_{2}$ に比べてわずかで ある。原点から遠い根軌跡は， $q_{3}$ 単独の根軌跡と同様 な動きを示す。したがって， $q_{4}$ は制振効果にはあまり 寄与しない.むしろ， $q_{4}$ の役割は，相対変位 $x_{d}$ の抑制 にある. $q_{4}$ を増加するにつれて相対変位が少なくなる ので，搆造的制約などから相対変位が規制される場合 には，この值を適量与えればよい，過度に与えると制 振効果が隇退するので注意を要する。

$4 \cdot 3$ 固有振功数比 $\gamma$ の影豐 以上は $\gamma=1$ に固 定した解析結果であるが、次に $\gamma$ の值を変えたときの 影望について調べてみよう。

図 10 は, $q_{1}=q_{3}=1, q_{2}=q_{4}=0, \bar{R}=1$ の基で、, 1 を 中心に $\gamma$ を変化させたときの制振効果, 消費エネルギ 一，および相対変位の最大值の解析結果をまとめたも のである．外力は，vがインパルス力として与えられ た。この場合の制振効果と消費エネルギーは，次のよ

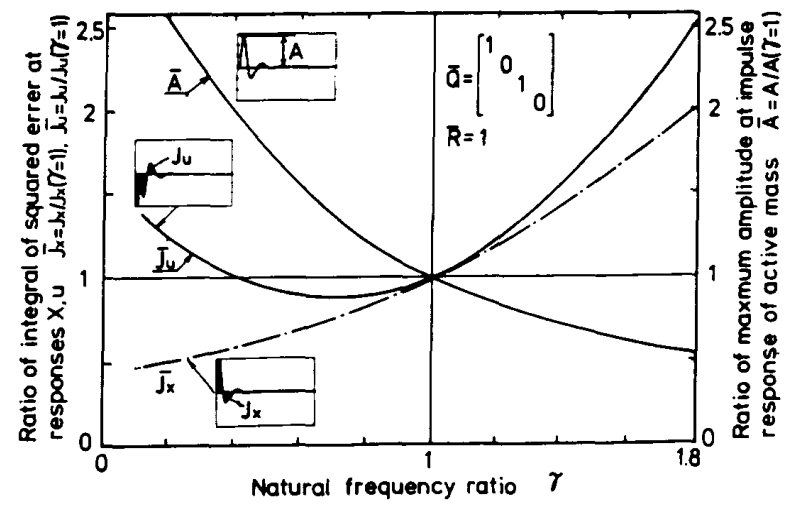

図 10 制振効果と制御エネルギーおよび相対変位の初期 応答に及ぼす固有振動数比の影隌 
うに定義した変位応答 $X$ の二乗面䅡 $(\mathrm{ISE}) J_{x}$ と, 制 御量 $u$ の二乗面箖 $J_{u}$ によって評価した。

$$
\begin{aligned}
& J_{x}=\int_{0}^{\infty} X^{2} d t \\
& J_{u}=\int_{0}^{\infty} u^{2} d t
\end{aligned}
$$

また, 相対変位の最大值はインパルス応答で初期に生 じる最大相対変位振幅で定義した。

この図から次のことがわかる，すなわち，消費エネ ルギーの最小做は $\gamma=0.8$ の付近にあり, 相対変位の 最大值と制振効果の曲線もその付近に折れ点がある. また， $\gamma$ をさくすれば制振効果が向上するが，反面 相対変位が大きくなる。一般に構造上の制約から相対 変位の取り得る筑囲に制限があるので, 相対変位を規 制すればその分制振効果も隇退する。

以上の結果から， $\gamma$ の最適値は 0.8 付近にありこ の值を 1 を越えて大きくすることは制振効果を低下さ せ，消費エネルギーを多くすることがわかった。

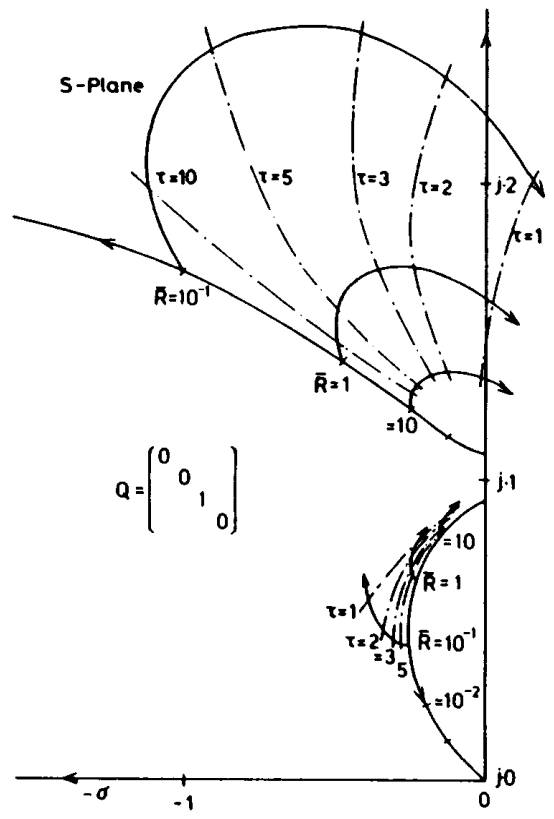

図 11 制振効果に及ほす時定数比 $\tau$ の新䈏を示す根軌跡

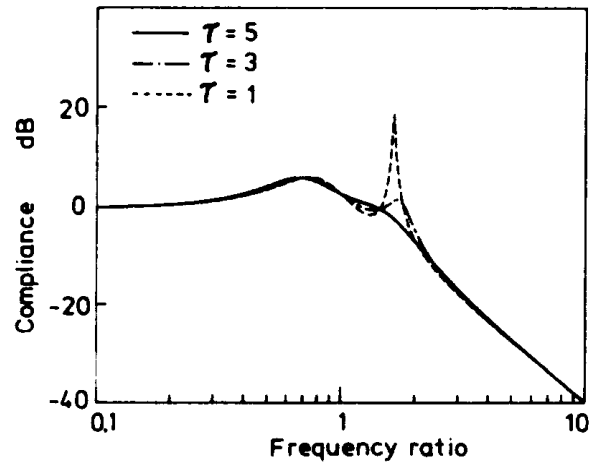

図 12 時定数比てが小さくなるにつれて安定性が堿じら れることを示す周波数応答
4・4 アクチュエータの功特性の暏管 次にアク チュエータの時定数が無視できない場合について調べ る.

図 11 は， $q_{3}$ 単独 $\left(q_{3}=1, q_{1}=q_{2}=q_{4}=0\right)$ で制御系を 設計した際，時定数比 $\tau$ の值によって二つの根が影警 される様子を根軌跡によって示したものである。この 図から， $\tau$ が大きいときは問題ではないが, $て$ の值が 小さくなるに連れて原点から遠方にある根軌跡が虚軸 に接近し，ついには不安定にいたることがわかる。一 方，原点に近い根軌跡はほとんど影䇾されていない。

このての值と周波数特性の関係を図 12 に示す。 れらの図から概略見当がつくことは， $\tau$ の值が 5 以上 であれば式(33)を用いた制御系設計に特に問題はない が，てがさらに小さくなるに伴い高域周波数で制御系 の安定度が損なわれることである。このことは速度に 重みを掛けた場合のほうがより影著である。

したがって，この問題を避けるには,アクチュエー 夕の時定数を小さくするか，式(31)による制御系設計 を行って, 電流フィードバックを加えた五つの状態 フィードバックなどの対応が必要となる。

5.

験

$5 \cdot 1$ 实験装嘈本実験には，一端が固定された

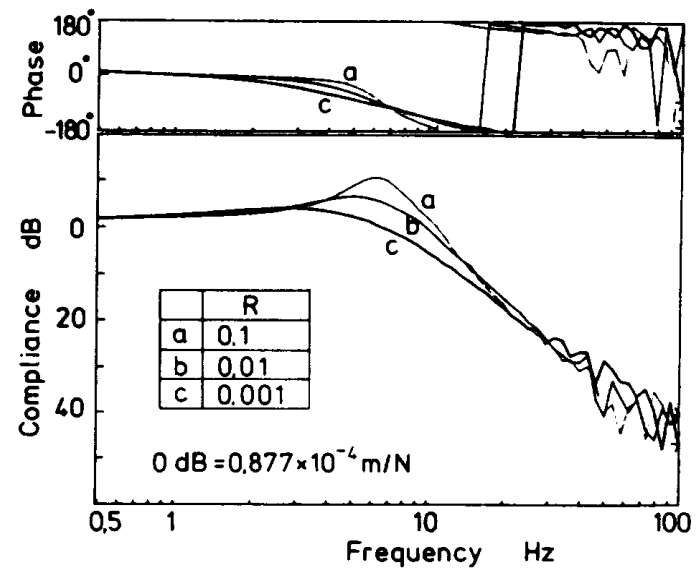

図 13 図 5 に対応する周波数応答の実測値

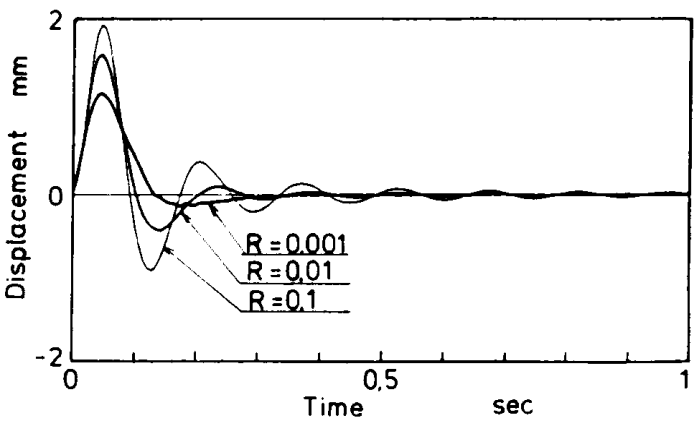

図 14 図7(a)に対応するインパルス応答の実測值 
並列板ばねと質量から成る制振対象を用いた。これに 図 1 に示した能動的動吸振器が取付けられている。制 振対象の変位信号 $X$ は板ばねに張り付けたひずみゲ ージによって検出し，相対変位 $x_{d}$ はインダクタンス 変換形変位計で検出している. 各信号は微分回路を通 して速度信号に変換され, 以上の四つの信号を状態 フィードバックして制御量 $u$ を得ている。本実験装置 の諸元は次の值である.

$$
\begin{array}{ll}
M=5.34 \mathrm{~kg}, & K=1.14 \times 10^{4} \mathrm{~N} / \mathrm{m} \\
m=0.34 \mathrm{~kg}, & k=7.77 \times 10^{2} \mathrm{~N} / \mathrm{m} \\
K_{c} / R=1.22 \mathrm{~N} / \mathrm{V}, & K_{s}=1 \times 10^{3} \mathrm{~V} / \mathrm{m} \\
1 / T=282 \mathrm{rad} / \mathrm{s} &
\end{array}
$$

$5 \cdot 2$ 实験結果制振効果の解析結果を検証する ために行った実験の結果を次に示す．上記の諸元によ れば，実験装置の無次元量は次のようになっている。

$$
\mu=0.0637, \gamma=1.035, \tau=6.13, R=0.011 \bar{R}
$$

これらの数值は理論解析に用いた無次元量とほぼ同じ 值であるので，この装置により得られる実験結果は図 4 〜図 7 に示した解析結果と対比できる.

図 13 は, $q_{3}=1$ として制振対象の変位に単独に重み を掛けて, 重み係数を $R=0.1,0.01,0.001$ の 3 段階に 変化させた時の周波数応答の実験結果である。これは， 図 5 の理論解析結果に相当する。本装置ではアクティ ブ質量がリニア案内面で支持されているので，Rが大 きくて制御量が小さい場合には, 案内面の摩擦の影響 で共振ピークの特徵がわずかに異なるが，その他は両 者の良い一致が見られる。

また，図 14 についても同様に図 7 (a)に相当する インパルス応答の実験結果である。どちらもよく対応 しており，理論解析で示された制振効果は，実験によ つても同様な結果を示すことがわかる. 特に, 重み $R$ を小さくするに連れて初期応答が抑制されることは注 目される。これは受動的動吸振器では得ることのでき ないものであり，ランダム外力に対しても優れた制振 効果があることを示す。

\section{6. 結綸}

LQ 制御理論を用いて能動的動吸振器の制御系を設 計して，今まで不明であった設計パラメータと制振効
果の関係を解明し，次の知見を得た。

（1）一般性ある制御系設計の料が得られるよう に, 制御系を無次元化表示した。

(2) 無次元系と次元系の相互変換のための相似則 を示した。これによって，無次元系で調べられた結果 が実際の装置の設計に直接利用できることになった。

(3) 制振対象の変位と速度に掛かる重み係数 $q_{3}$, $q_{1}$ と, 相対変位と相対速度に掛かる重み係数 $q_{4}, q_{2}$ の 四つの設計パラメータが制振効果に及ほす影警を明ら かにすることができた，その結果，従来試行鎖誤的に 行われていた重み係数の決定法を，定量的，かつ確定 論的に決定できるようにした。

（4）制御系設計におけるアクチュエータの動特性 の無視できる限界を示した。

（5）消費エネルギーを最小にする動吸振器の固有 振動数を示した。

（6）理論解析結果の妥当性を実験によって確認し た。特に、ここで構成した能動的動吸振器が衝撃的外 力に対する初期変位の抑制に優れていることを実験に よって示した。

\section{文献}

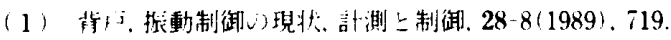

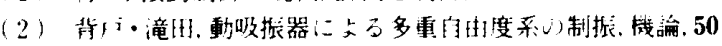
$-458, C(1984), 1962$

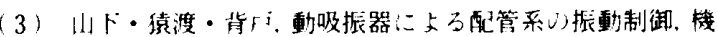
䛥, 55-518, C (1989), 2511.

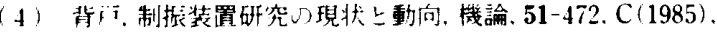
3165 .

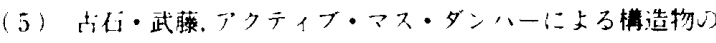

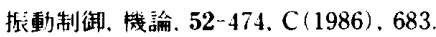

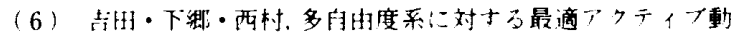
吸掉器, 㼄論, 54-508, C (1988), 2948.

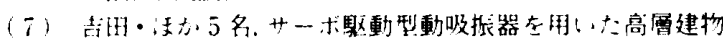

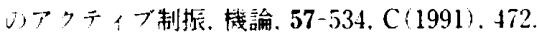

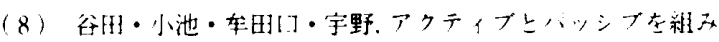

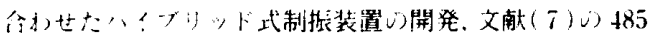
メジ.

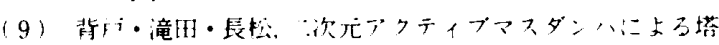

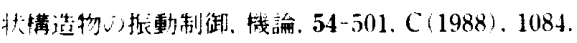

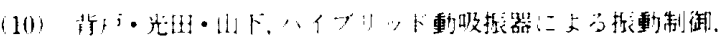
文献(7)J) 478 ハージ

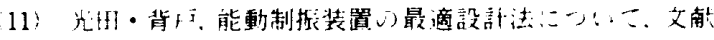
T) 393 - 